\title{
Pyrochemical Investigations into Recovering Plutonium from Americium Extraction Salt Residues
}

\author{
Keith W. Fife \\ Michael H. West
}

DISCLAIMER

\begin{abstract}
This repont was prepared as an account of work sponsored by an agency of the United States Government. Neither the United Siates Government nor any agency thereof, nor any of their employees, makes any warranty, express or implied, or assumes any legal liability or responsibility for the accuracy, completeness, or usefulness of any information, apparatus, product, or process disclosed, or represents that its use would not infringe privately owned rights. Reference herein to any specific commercial product, process, or service by trade name, trademark, manufaciurer, or otherwise does not necessarily constitute or imply its endorsement, recommendation, or fayoring by the United States Government or any agency thereof. The views and opinions of authors expressed herein do not necessarily state or reflect those of the United States Government or any agency thereof.
\end{abstract}




\title{
PYROCHEMICAL INVESTIGATIONS INTO RECOVERING PLUTONIUM
}

FROM AMERICIUM EXTRACTION SALT RESIDUES

\author{
by
}

Keith W. Fife and Michael $\mathrm{H}$. West

\begin{abstract}
Progress into developing a pyrochemical technique for separating and recovering plutonium from spent americium extraction waste salts has concentrated on selective chemical reduction with lanthanum metal and calcium metal and on the solvent extraction of americium with calcium metal. Both techniques are effective for recovering plutonium from the waste salt although neither appears suitable as a separation technique for recycling a plutonium stream back to mainline purification processes.
\end{abstract}

I. AMERICIUM REMOVAL BY MOLTEN SALT EXTRACTION

At Los Alamos, the Plutonium Metal Technology Group (MST-13) routinely recovers and purifies plutonium metal from a variety of impure feed streams. The batch unit operations are pyrochemical and consist of controlling oxidation and reduction reactions between plutonium metal and its compounds in molten salt environments . 1

Americium-241 grows into plutonium by beta decay of ${ }^{241} \mathrm{Pu}$ at a rate proportional to the ${ }^{241} \mathrm{Pu}$ isotopic concentration. The americium is periodically removed from the plutonium because it is an impurity and because it produces gamma radiation during its alpha decay to ${ }^{237} \mathrm{~Np}$.

The established technique for removing high concentrations of americium from plutonium metal is molten salt extraction (MSE). MSE is a batch process and consists of contacting molten plutonium metal with a molten oxidizing salt. ${ }^{2,3}$ The salt for this process is $\mathrm{MgCl}_{2}$ dissolved in either equimolar $\mathrm{NaCl}-\mathrm{KCl}$ or in one of the low-melting $\mathrm{KCl}-\mathrm{CaCl}_{2}$ eutectics.

The thermodynamic basis for the americium-plutonium separation is illustrated in Table I, which lists free energies of formation for several metal chlorides. ${ }^{4}$ 


\section{TABLE I}

Free Energies of Formation at $1000 \mathrm{~K}$ for Several Metal Chlorides

$\begin{array}{lc}\text { Salt } & -\Delta \mathrm{G}_{\mathrm{f}} \text { (kcal/g-atom chloride) } \\ \mathrm{Kal} & 81 \\ \mathrm{CaCl}_{2} & 78 \\ \mathrm{NaCl} & 76 \\ \mathrm{AmCl}_{3} & 67 \\ \mathrm{LaCl}_{3} & 67 \\ \mathrm{PuCl}_{3} & 59 \\ \mathrm{MgCl}_{2} & 58\end{array}$

From these free energy changes, the following reactions are expected to occur:

$$
\begin{array}{ll}
2 \mathrm{Pu}^{0}+3 \mathrm{MgCl}_{2}+2 \mathrm{PuCl}_{3}+3 \mathrm{Mg}^{0} & \Delta \mathrm{G}(1000 \mathrm{~K})=-3 \mathrm{kcal} / \mathrm{mole} \\
2 \mathrm{Am}^{\mathrm{o}}+3 \mathrm{MgCl}_{2} \rightarrow 2 \mathrm{AmCl}_{3}+3 \mathrm{Mg}^{\mathrm{o}} & \Delta \mathrm{G}(1000 \mathrm{~K})=-27 \mathrm{kcal} / \mathrm{mole} \\
\mathrm{Am}^{\mathrm{o}}+\mathrm{PuCl}_{3} \rightarrow \mathrm{AmCl}_{3}+\mathrm{Pu}^{0} & \Delta \mathrm{G}(1000 \mathrm{~K})=-24 \mathrm{kcal} / \mathrm{mole}
\end{array}
$$

The partitioning of americium and plutonium (by oxidation-reduction reactions) has been studied by Knighton et al. ${ }^{3}$ They report distribution coefficient $(\mathrm{Kd})$ relationships for americium and plutonium between molten salt and molten plutonium as a function of initial $\mathrm{MgCl}_{2}$ concentration in the extraction salts. For $\mathrm{MgCl}_{2}$ dissolved in equimolar $\mathrm{NaCl}-\mathrm{KCl}$ at $750^{\circ} \mathrm{C}$, the relationships are

$$
\begin{aligned}
& \mathrm{Kd}(\mathrm{Am})=273.7\left(\mathrm{X}_{\mathrm{MgCl}_{2}}\right)^{1.5} \\
& \mathrm{Kd}(\mathrm{Pu})=0.692\left(\mathrm{X}_{\mathrm{MgCl}_{2}}\right)^{1.5},
\end{aligned}
$$

where $\mathrm{X}_{\mathrm{MgCl}_{2}}=$ mole fraction $\mathrm{MgCl}_{2}$ in the equimolar diluent $\mathrm{NaCl}-\mathrm{KCl}$ and 
$\mathrm{Kd}($ solute $)=\frac{\text { wto solute in salt phase }}{\text { wto solute in metal phase }}$.

The separation factor for two solutes partitioning between two solvents is defined as the ratio of their distribution coefficients. The separation factor for americium-plutonium in equimolar $\mathrm{NaCl}-\mathrm{KCl}$ is the ratio of the distribution coefficients for americium and plutonium partitioning between the molten salt and plutonium phases:

$$
\text { separation factor }=\mathrm{Kd}(\mathrm{Am}) / \mathrm{Kd}(\mathrm{Pu})=273.7 / 0.692-396
$$

At Los Alamos, MSE is not a routine production operation and is performed relatively infrequently. For accountability and personnel exposure reasons, we dispose of products and residues as quickly as possible. For these reasons, a crosscurrent extraction mode meets our needs very well (Fig. 1a). In contrast, Rocky Flats Plant practices MSE on a production basis and has adopted the more efficient countercurrent contacting mode to optimize extraction erficiency and residue generation.

Crosscurrent extraction uses a fresh salt for each metal contact and although overall extraction efficiencies can be higher than in countercurrent extraction, waste salt generation is also high. In multistage crosscurrent MSE, one waste salt is generated per extraction stage during the purification of one batch of plutonium metal (Fig. 1a). Conversely, in countercurrent extraction, the salt and metal streams move in opposite directions through the contact stages. In multistage countercurrent MSE, only one waste salt is generated for each batch of plutonium metal purified (Fig. 1b). There are, however, several salts and batches of plutonium metal in various stages of processing.

Los Alamos typically performs MSE with $\mathrm{MgCl}_{2}$ dissolved in equimolar NaCl-KC1. The high $\mathrm{KCl}$ eutectic of $\mathrm{CaCl}_{2}-\mathrm{KCl}$ has also been investigated as an alternative to $\mathrm{NaCl}-\mathrm{KCl}$. These salts were chosen because their eutectic compositions are relatively low melting (equimolar $\mathrm{NaCl}-\mathrm{KCl}$ at $660^{\circ} \mathrm{C}$ and $\mathrm{CaCl}_{2}-60$ molo $\mathrm{KCl}$ at $650^{\circ} \mathrm{C}$ ) and the constituents are inert in the MSE redc $\mathrm{K}$ reactions. 


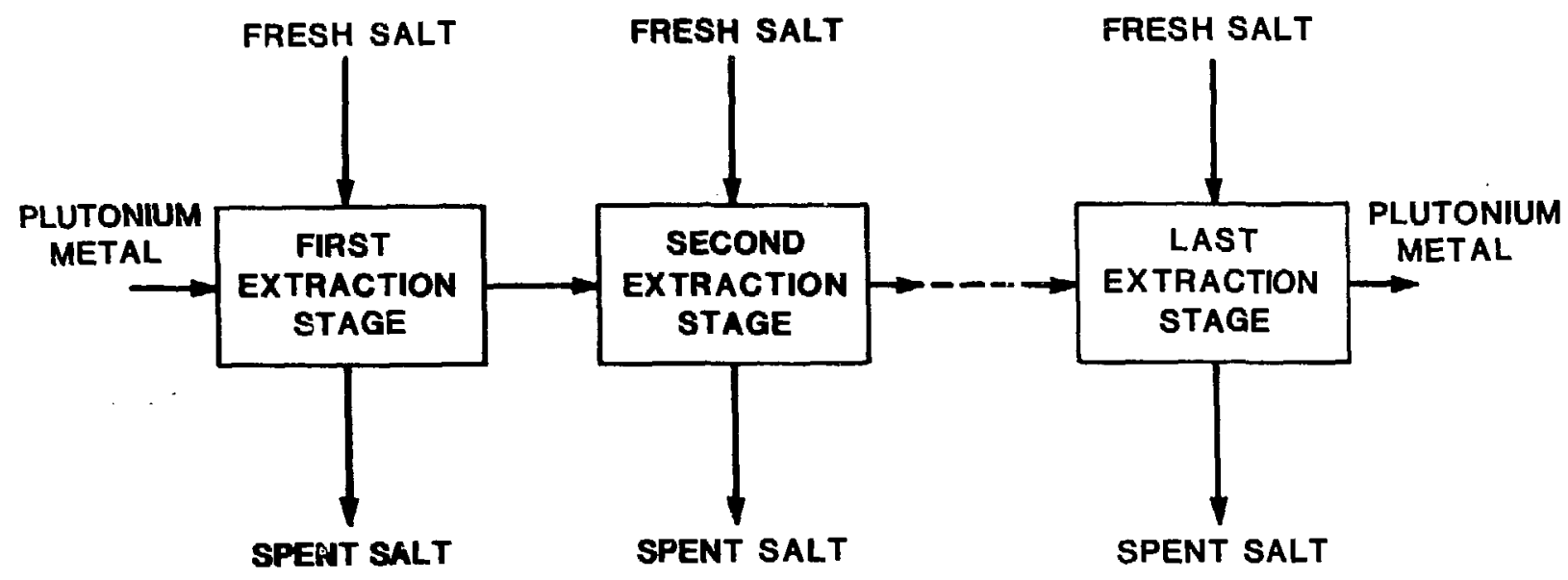

Fig. 1a. Grosscurrent molten salt extraction.

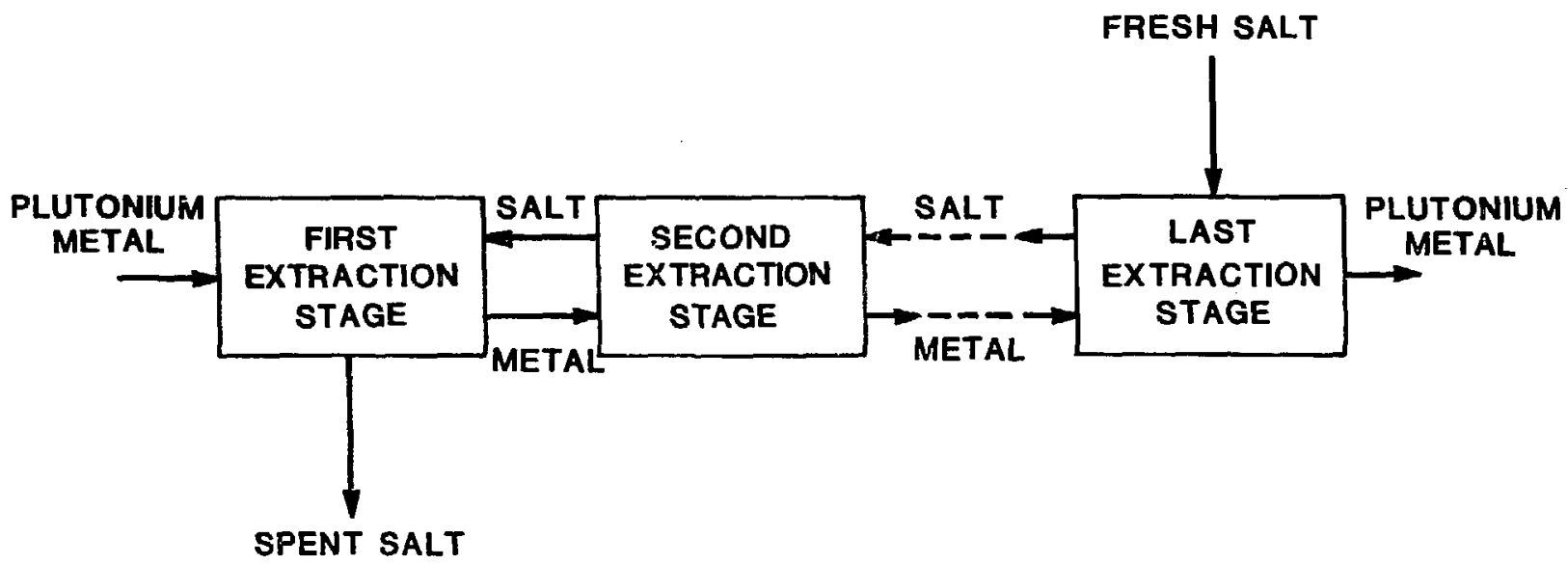

Fig. 1b. Countercurrent molten salt extraction.

Unfortunately, $\mathrm{MgCl}_{2}$ also co-oxidizes significant quantities of plutonium with the americium during MSE [reaction (1)]. This results in a waste salt that cannot be discarded and must be treated to recover the plutonium inventory. Among the flowsheets treating this residue, only the aqueous procedures have the ability to effectively separate the plutonium and americium during recovery. 5-8 There are several pyrochemical flowsheets' with the capability of treating this residue, but no separation between the two constituents has been effectively 
demonstrated at this point.9-12 Los Alamos has investigated various chemical reduction alternatives with the principal objective being to separate and recover a relatively pure plutonium stream for recycle into mainline purification processes.

II. EQUIPMENT

The basic equipment used for MSE and in our MSE salt-stripping experimentation is shown in Fig. 2 and is common to most pyrochemical operations at Los Alamos. All of our molten salt reactions take place in highly vitrified magnesia crucibles contained in a series of concentric vessels: a $23-\mathrm{cm}-1$ long by 13-cm-diameter magnesia crucible located inside a tantalum safety can, which in turn is inside a stainless steel loading can. This assembly is finally sealed in a furance tube under an argon atmosphere.

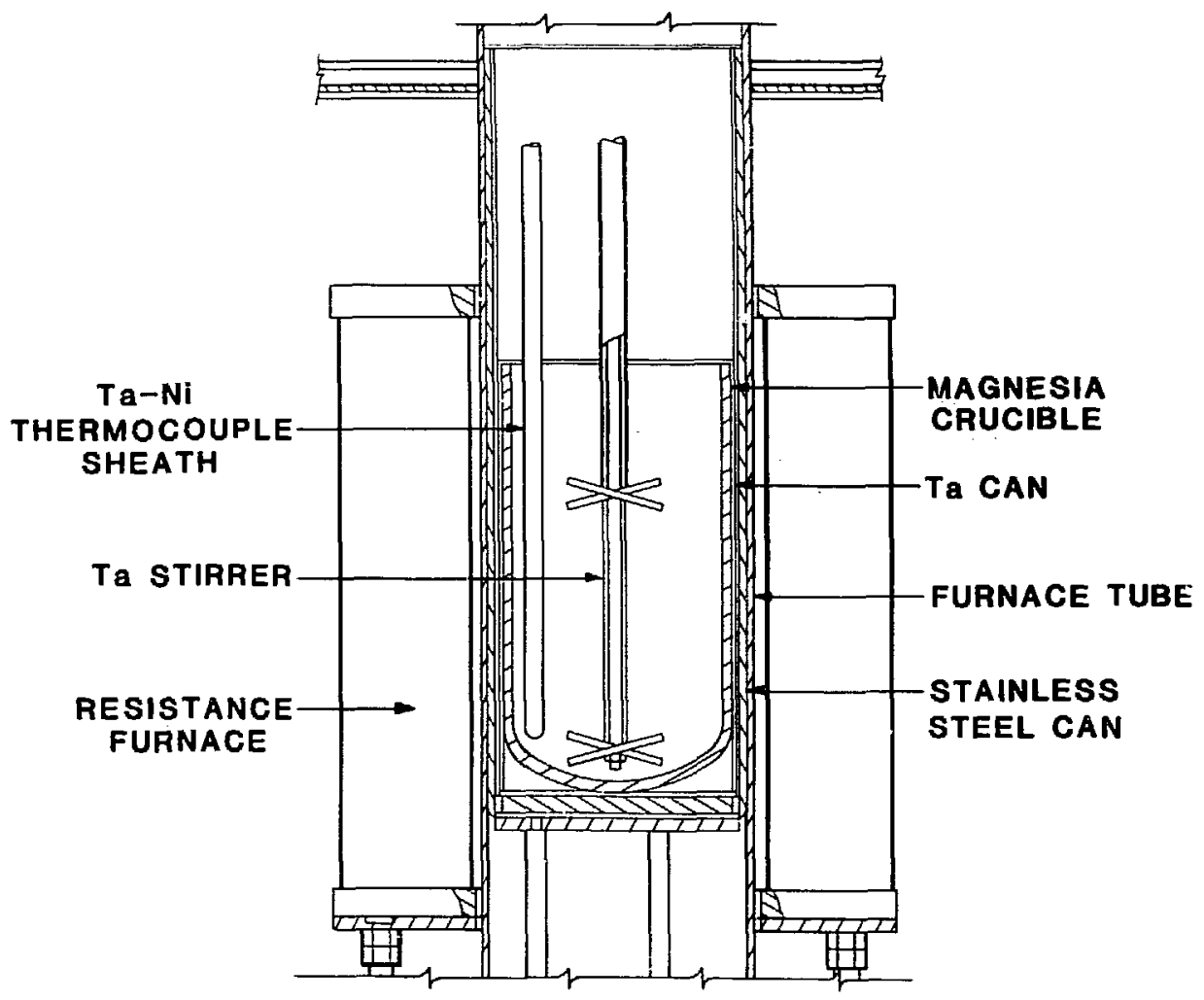

Fig. 2. Pyrochemical process equipment used for MSE and MSE salt stripping. 
Using a Lindberg Mode1 $6015 \mathrm{~S}$ resistance furnace, vessels and their contents are heated to the reaction temperature $\left(800-850^{\circ} \mathrm{C}\right)$ and agitated with a tantalum stirrer. Temperature is measured by a Chromel-Alumel thermocouple immersed in the melt and protected by a tantalum-nickel sheath. The composite sheath with nickel inside the tantalum is strong mechanically and is resistant to both the reaction mixture and to air oxidation.

\section{EXPERIMENTAL RESULTS}

Feed to the batch salt-stripping process was either $\mathrm{NaCl}-\mathrm{KCl}-\mathrm{MgCl}_{2}-\mathrm{PuCl}_{3}$ $\mathrm{AmCl}_{3}$ or $\mathrm{CaCl}_{2}-\mathrm{KCl}-\mathrm{MgCl}_{2}-\mathrm{PuCl}_{3}-\mathrm{AmCl}_{3}$ (Fig. 3). The salts weighed between 1.5 and $2.5 \mathrm{~kg}$ and contained 5-10 wto plutonium and 0.1-3 wto americium.

For recovering and separating plutonium from spent MSE salts, we investigated three pyrochemical techniques:

- reduction of $\mathrm{PuCl}_{3}$ and $\mathrm{AmCl}_{3}$ and the subsequent extraction of americium metal into excess calcium metal,

- selective reduction or titration of $\mathrm{PuCl}_{3}$ with substoichiometric amounts of calcium metal, and

- selective reduction of $\mathrm{PuCl}_{3}$ with lanthanum metal.

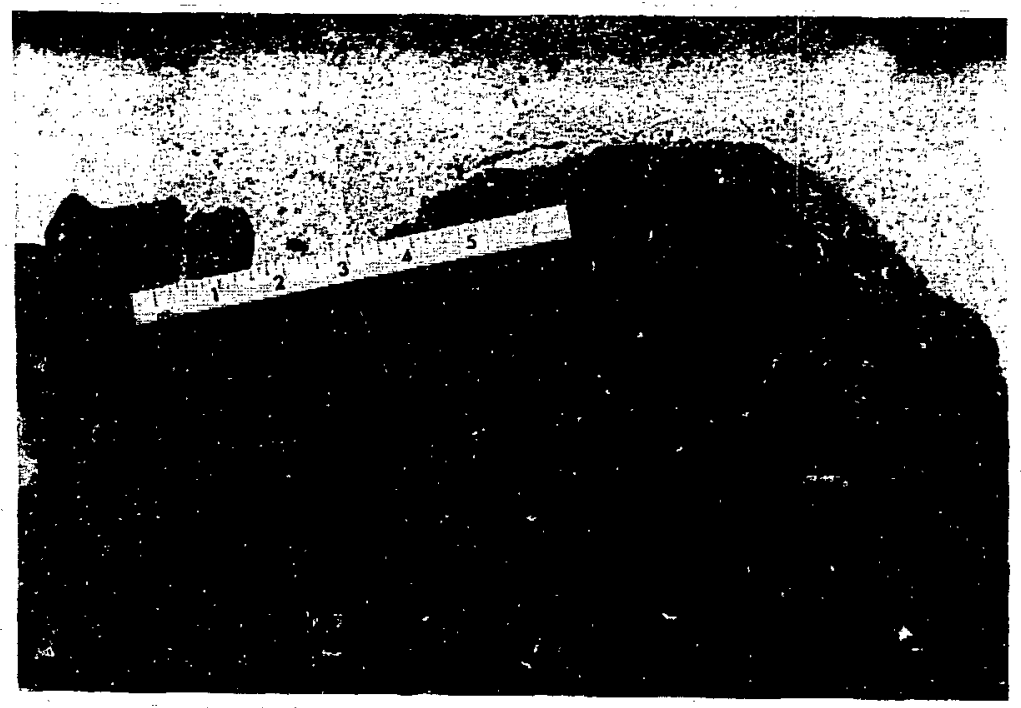

Fig. 3. Typical spent MSE salt. 


\section{A. Solvent Extraction}

The extraction of americium was investigated because early salt-stripping experiments with a large calcium excess resulted in quantitative plutonium recovery, a discardable salt, and a significant partitioning of americium into the excess calcium phase. In several early experiments, the product metal consisted of two mechanically separable phases (Figs. 4 and 5). The top phase analyzed in excess of $80 \mathrm{wt} *$ calcium metal, <10 wtz plutonium, and -10 wtz americium. The bottom phase analyzed in excess of 90 wto plutonium and <10 wto americium. While this was still too high in americium content for direct recycle, it was suitable for recycle back to MSE. Further experimentation with this technique illustrated that mechanical phase separation is not possible with all product metal. Figure $\sigma$ is a photograph of more typical product metal resulting from. salt stripping with excess calcium. This metal is also twophase, but it is not amenable to mechanical separation for plutonium recovery and americium removal. Typical metallography of product metal from excess calcium reduction is shown in Fig. 7. The two major regions of the button contained significant quantities of magnesium. The upper region was a multiphase dendritic structure with relatively large calcium-rich crystallites and plutonium-rich particles in a magnesium-rich matrix. The lower, plutoniumrich region was populated with relatively large magnesium-calcium globules surrounded by plutonium. Large voids in this region contained calcium and

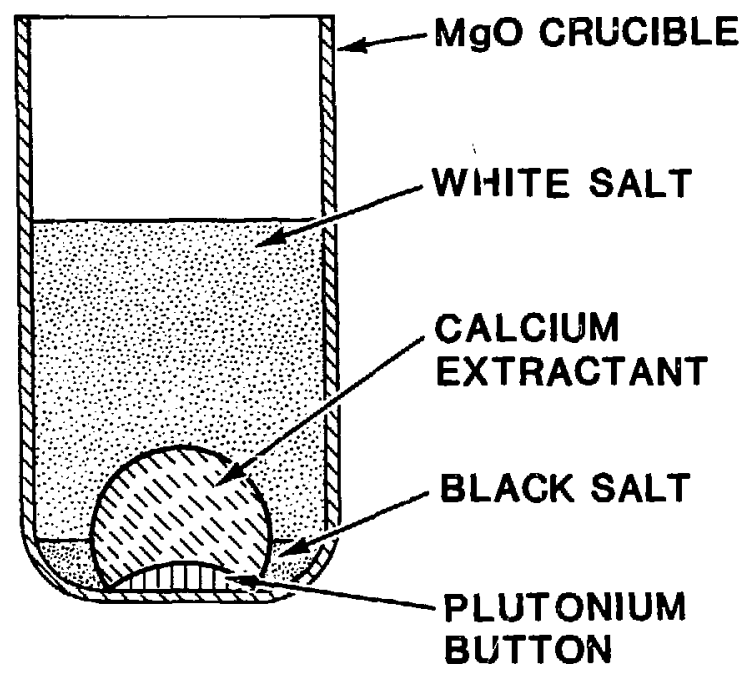

Fig. 4. Solvent extraction/salt stripping of MSE salt residues. 


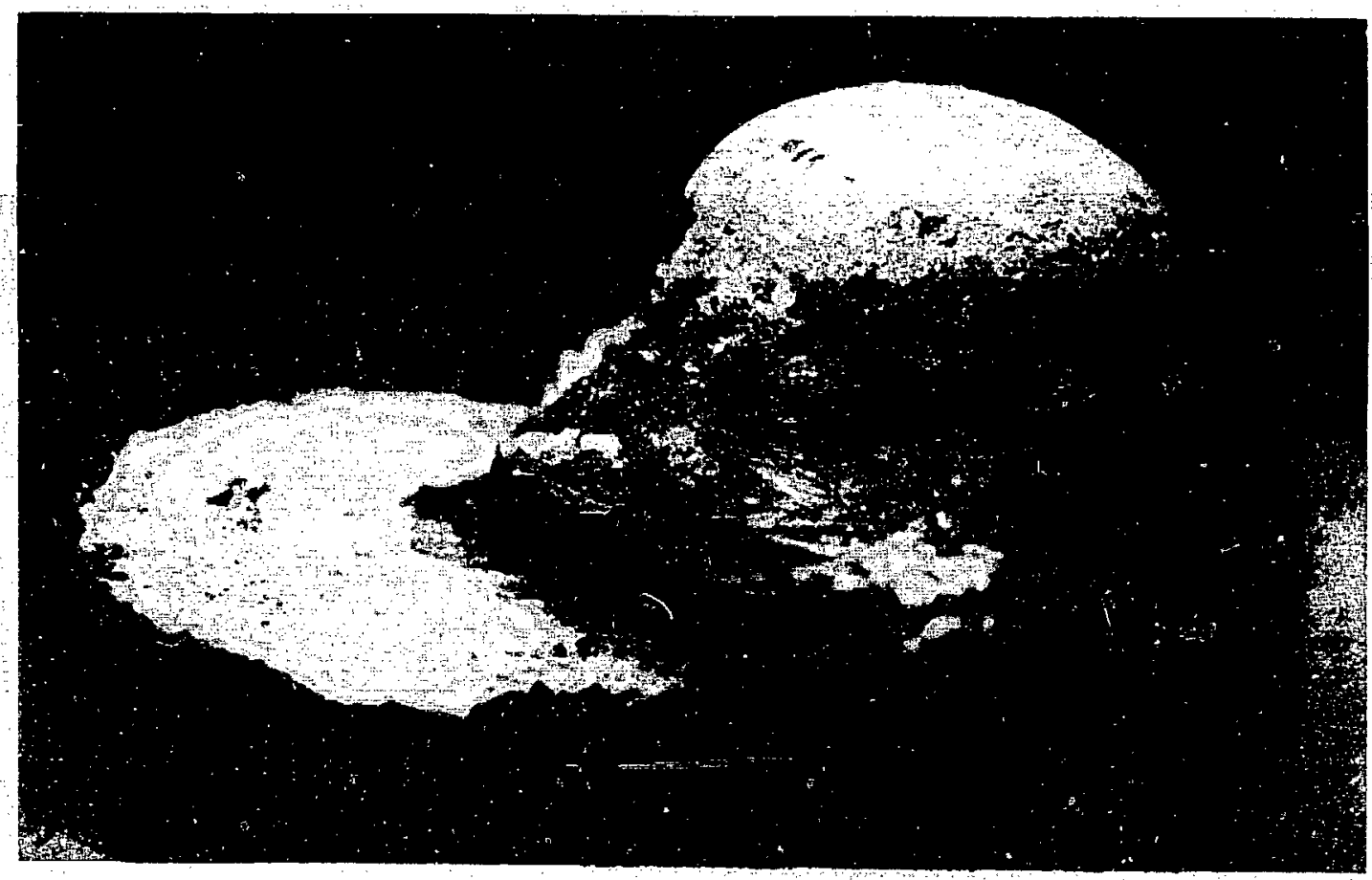

Fig. 5. Product phases after separation.

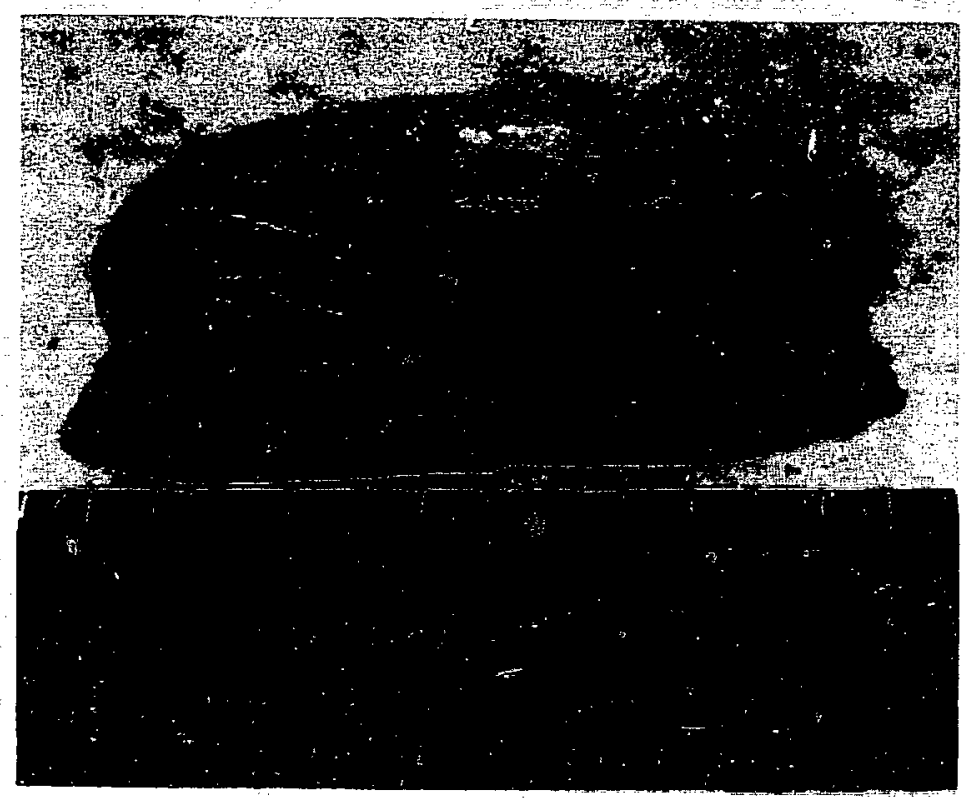

Fig. 6. Two-phase MSE salt-stripping product not amenable to mechanical phase separation. Plutonium-rich region is at the top. 


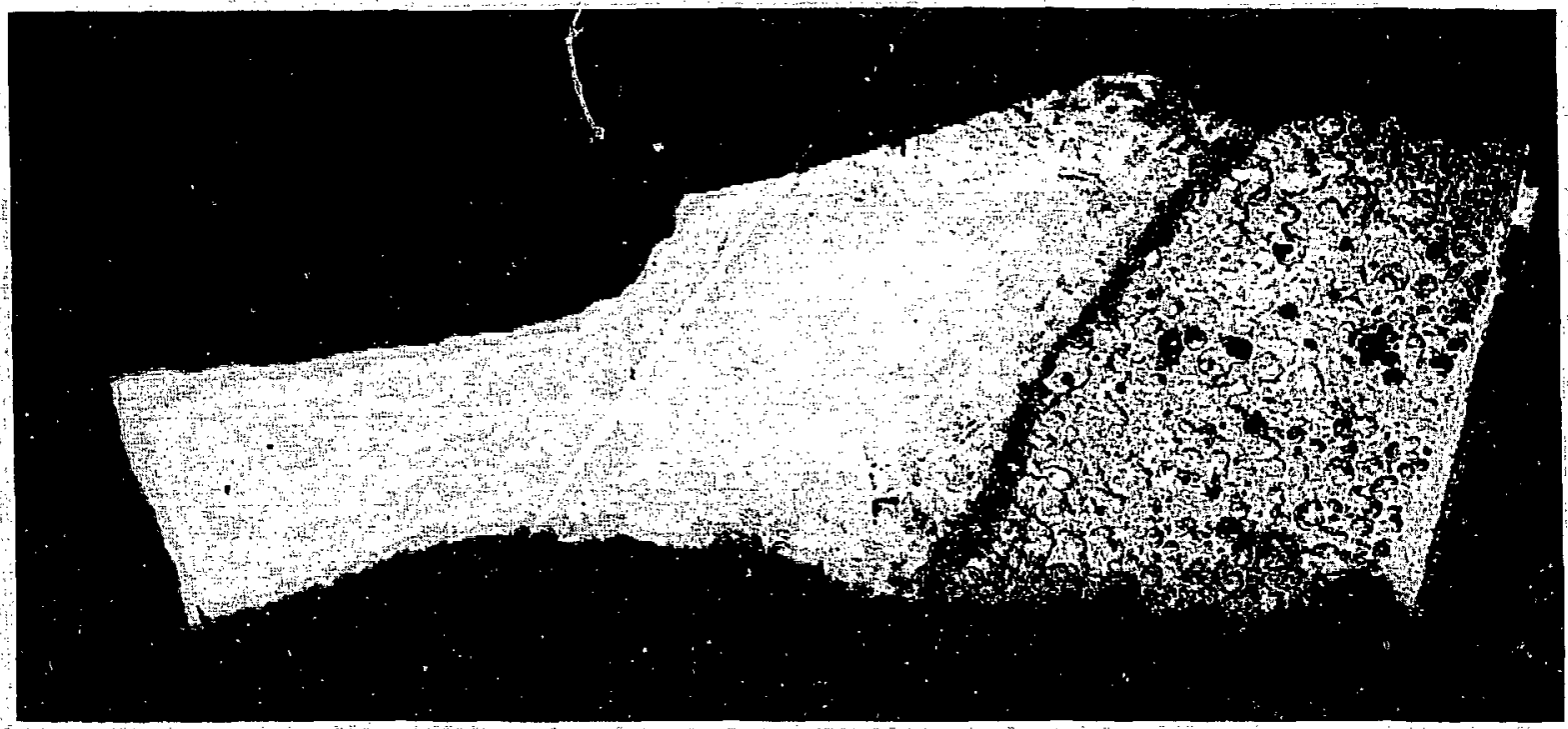

Fig. 7. Ion-etched cross section (10x magnification) of Pu-Am-Ca-Mg metal from excess calcium metal reduction of a spent MSE salt (upper region at the left; lower region at the right).

magnesium chlorides. Plutonium-rich fragments at the bottom of the button contained significant amounts of iron, whereas other fragments at the bottom were magnesium-rich with lesser amounts of calcium, plutonium, and americium. The magnesium preseat in this region could have resulted from plutonium attack on the adjacent Mg0 crucible surface. In general, americium seemed to be associated with the phases containing significant amounts of magnesium and plutonium. Qualitatively, the too side of the button provided more gross gamma activity than the bottom side, which suggested a higher americium concentration in the upper portion of the button.

If the primary goal from salt-stripping MSE salts is to produce a discardable salt phase and to concentrate the plutonium values into a small volume for future treatment, then excess calcium reduction is adequate for the purpose. However, since we are also interested in separating plutonium from americium, excess calcium reduction is not a suitable approach.

\section{B. Selective Reduction or Titration With Calcium Metal}

An alternate method to provide plutonium separation and a reasonable level of purification is the selective reduction or titration of $\mathrm{PuCl}_{3}$ in the molten salt with calcium metal. This technique relies on the free energy difference 
between $\mathrm{PuCl}_{3}, \mathrm{MgCl}_{2}$, and $\mathrm{AmCl}_{3}$ in the salt systom (about $8 \mathrm{kcal}$ from the data in Table I).

The procedure for this technique involves melting the feed salt (NaCl-KCl$\mathrm{MgCl}_{2}-\mathrm{PuCl}_{3}-\mathrm{AmCl}_{3}$ ) and incrementally adding calcium metal to reduce or titrate only the plutonium-magnesium salts. If controlled properly, this selective reduction produces only plutonium and magnesium metal, whereas americium remains dissolved in the salt. When this precipitate is aliuwst to rravitynsensute from the molten salt, it results in qualitative plutonium recovery and americium separation. If the titration is carried too far, however, the $\mathrm{AmCl}_{3}$ will also be reduced, and the result is similar to the addition of excess calcium metal.

To illustrate the feasibility of this technique, Figs. 8a, 8b, and $8 \mathrm{c}$ were created based on data from incremental calcium addition and stirring followed by a short period of settling and then sampling the upper region of the molten salt. These figures show that plutonium can be precipitated from the salt by reduction and gravity separation while the americium values remain essentially unchanged. This occurs until an excess amount of calcium has been added over the amount necessary to reduce both the $\mathrm{PuCl}_{3}$ and $\mathrm{MgCl}_{2}$ salts.

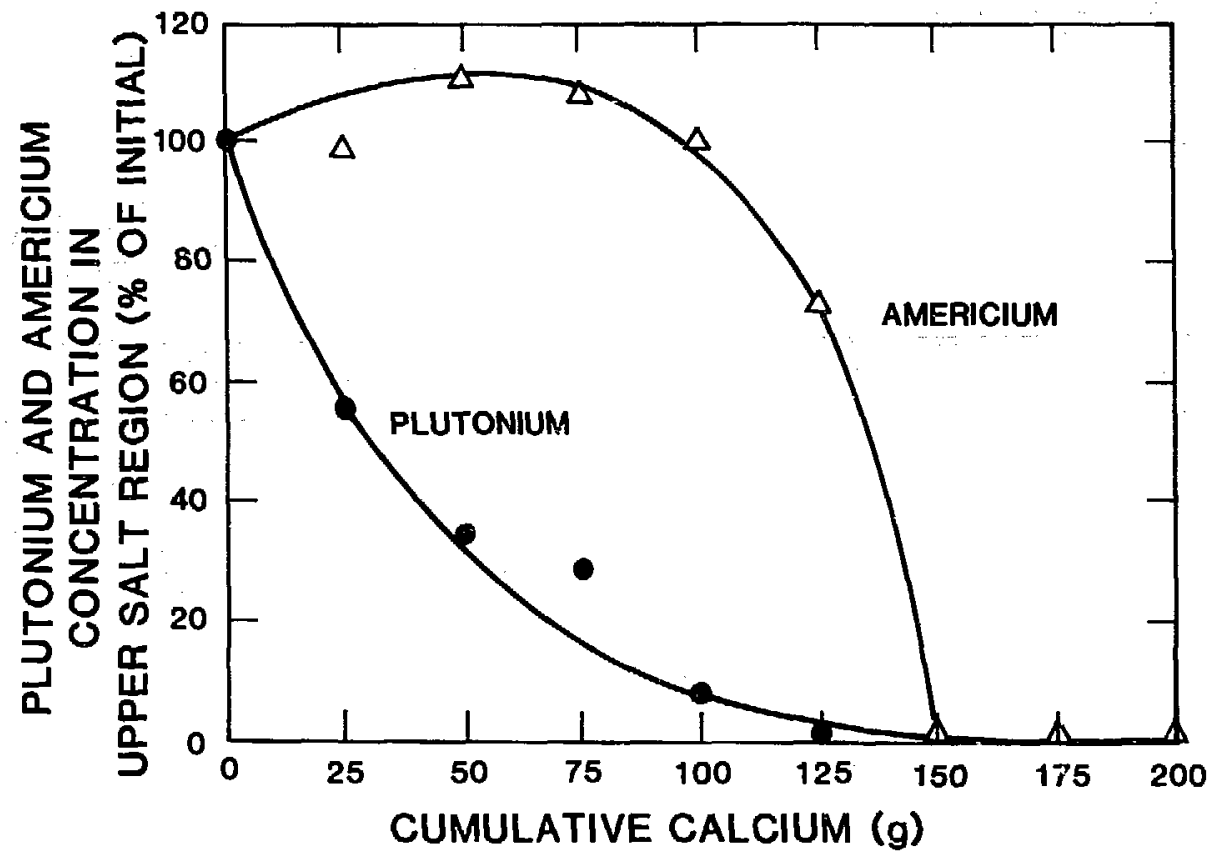

Fig. 8a. Bulk-salt results from titrating spent MSE salts (generated at Los Alamos) using calcium metal. 


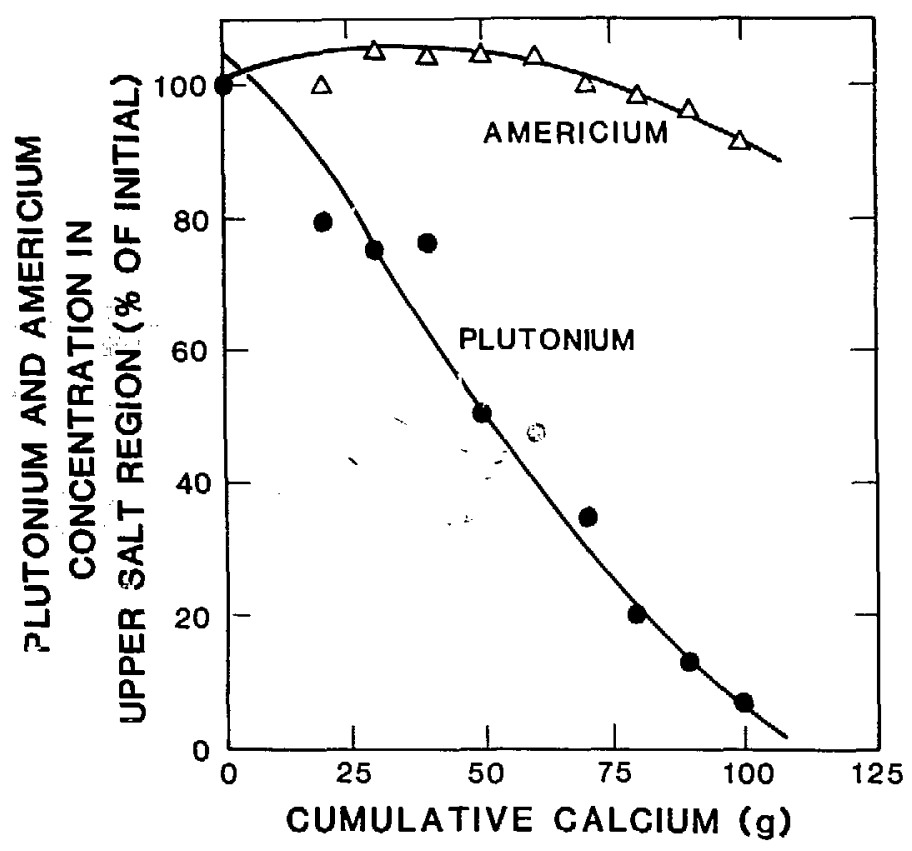

Fig. 8b. Bulk-salt results from titrating spent MSE salts (genexated at Los Alamos) using calcium metal.

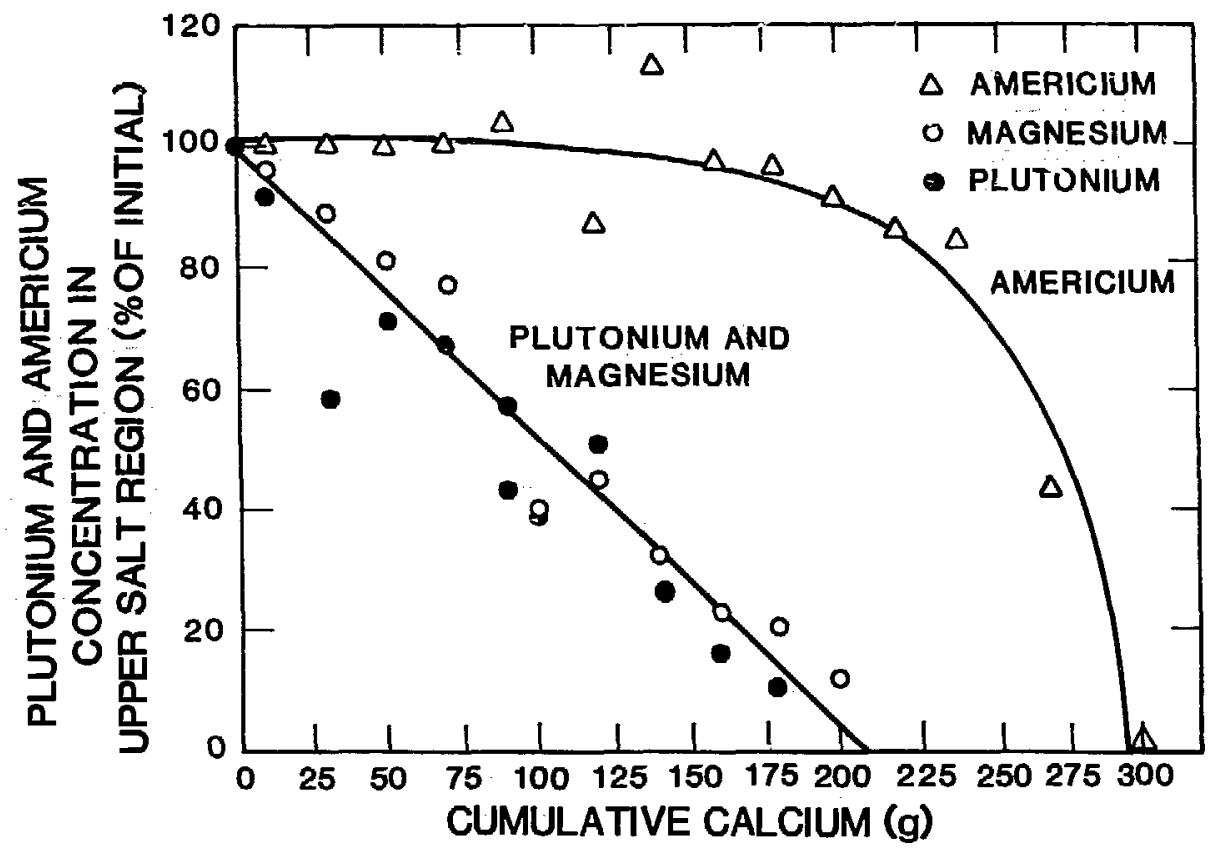

Fig. 8c. Bulk-salt results from titrating spent MSE salts (generated at Rocky Flats Plant) using calcium metal. 
The ultimate americium removal efficiency for this procedure is directly related to the settling efficiency of the dispersed metal. After the salts cool, final plutonium recovery from these titration runs consists of mechanicaliy separating the plutonium-rich salt from the plutonium-lean salt (Fig. 9) and coalescing them in a reducing environment using calcium metal. If the settling efficiency of the plutonium metal is poor in the original titration, then more bulk salt containing $\mathrm{AmCl}_{3}$ is cycled to the final reduction step and the overall americium separation is poor.

From this type of experimentation, a metal product button was collected and reacted with $\mathrm{K}_{3} \mathrm{PuCl}_{6}{ }^{*}$ to remove residual americium [reaction (3)] and calcium:

$$
2 \mathrm{~K}_{3} \mathrm{PuCl}_{6}+3 \mathrm{Ca} \rightarrow 2 \mathrm{Pu}^{0}+3 \mathrm{CaCl}_{2}+6 \mathrm{KCl} \quad \Delta \mathrm{G}(1000 \mathrm{~K})=-57 \mathrm{kcal} / \mathrm{mole} \mathrm{PuCl}_{3}
$$

or

$2 \mathrm{PuCl}_{3}+3 \mathrm{Ca}^{\mathrm{O}}+3 \mathrm{CaCl}_{2}+2 \mathrm{Pu}^{\circ}$

"The $\mathrm{K}_{3} \mathrm{PuCl}_{6}$ was prepared by substoichiometric oxidation of pure plutonium metal with $\mathrm{ZnCl}_{2}$ in $\mathrm{KCl}$.

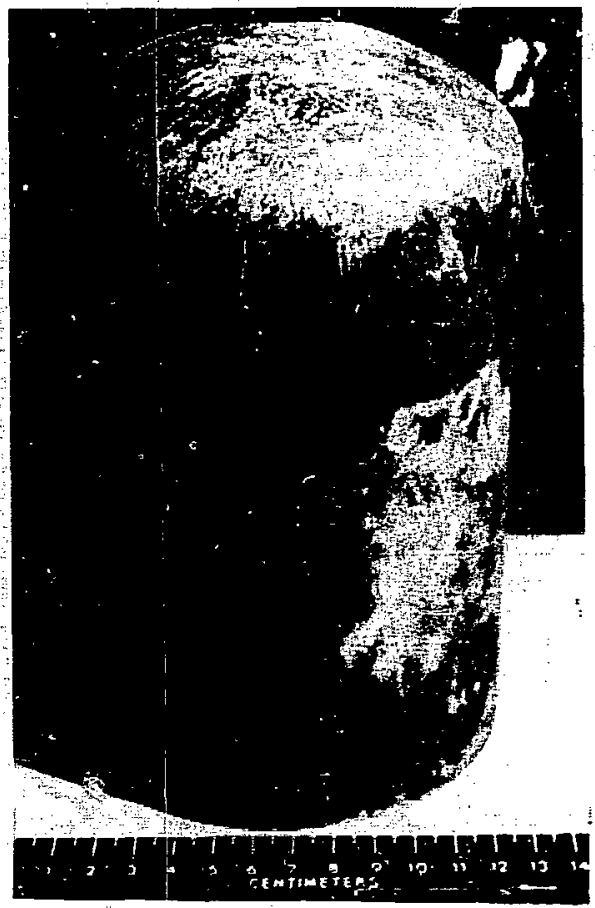

Fig. 9. Salt product from titration with calcium metal (shown inverted). The darker top region contains plutonium concentrate. 
The resulting metal product had a density of $9.7 \mathrm{~g} / \mathrm{cm}^{3}$ indicating corisiderable dilution of plutonium by magnesium. Overall, the plutonium content of the button was 89.68 as determined by calorimetry. A cross section of the metal product revealed four distinct regions (Fig. 10). The two lower regions fell within the "plutonium-rich" portion of the button (91.68 plutonium), whereas the remaining two regions were located in the "magnesium-rich" portion (51.68 plutonium). The following concentrations for calcium and americium were found in the plutonium-rich and magnesium-rich portions after reaction with $\mathrm{K}_{3} \mathrm{PuCl}_{6}$ :

$\begin{array}{lcc} & \frac{\mathrm{Ca}(\mathrm{ppm})}{\text { Magnesium-rich }} & \frac{\text { Ampm) }}{168} \\ \text { Plutonium-rich } & 20,000 & 35\end{array}$

Region A, Fig. 10, was composed of large grains of magnesium-rich plutonium-magnesium containing radiating needle-shaped inclusions of plutonium metal. Region $B$ contained grains of plutonium metal in a matrix of plutoniummagnesium. Region $C$ was primarily plutonium metal with inclusions of plutoniumiron and spherical inclusions of plutonium-magnesium. Rebion D contained grains of plutonium-carbide in a matrix of plutonium metal. The atomic composition was close to that of $\mathrm{Pu}_{2} \mathrm{C}_{3}$. The part of region $\mathrm{D}$ adjacent to the magnesia reaction crucible was very similar in composition and texture to region $B$, suggesting attack on the magnesia by plutonium metal.

We feel that for titration or substoichiometric reduction to advance as a candidate for further process development, a method is needed to accurately determine the amount of calcium necessary to reduce only the $\mathrm{PuCl}_{3}$ and $\mathrm{MgCl}_{2}$ salts or a technique needs to be developed to monitor unreduced $\mathrm{PuCl}_{3}$. In addition, the dispersed plutonium metal settling efficiercy needs to be maximized (namely, a technique approaching a molten salt centrifuge). Two alternatives are being investigated for accurately determining plutonium in the feed salt and during the titration reaction--improved nondestructive analytical (NDA) techniques for determining plutonium in the feed salt and electrochemical techniques for monitoring $\mathrm{PuCl}_{3}$ and $\mathrm{AmCl}_{3}$ in the molten salt.

lmproved NDA values would allow us to tailor calcium additions to react only with the plutonium and magnesium salts and leave the americium oxidized in the salt phase. The electrochemical techniques would allow us to monitor 


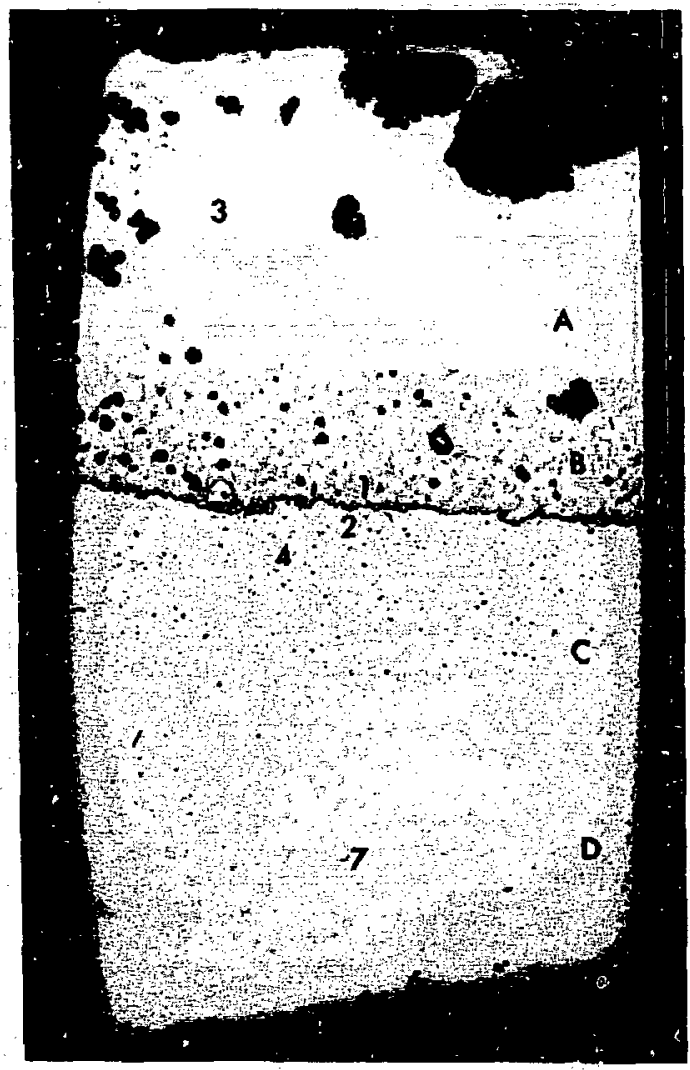

Fig. 10. Reflected light photomicrngraph (10x magnification) of a metal cross secțion from substoichiometric caicium metal reduction of spent MSE salt followed by reaction with $\mathrm{K}_{3} \mathrm{PuCl}_{6}$. Regions $A$ and $\bar{B}$ are magnesium-rich; regions $C$ and $D$ are pluconium-rich.

plutonium and americium concentration changes during titration experiments and stop calcium additions when the plutonium values are low and the americium values begin to consistently decrease.

Experimentation has begun in these areas, and currently we are studying $\mathrm{PuCl}_{3}$ and $\mathrm{AmCl}_{3}$ electrochemistry in various molten salt systems using voltammetric techniques. Improvement in NDA procedures is also under way. A technique under investigation by H. 0. Menlove and P. A. Russo, Group N-1, based on a modification of thermal neutron coincidence counting, ${ }^{13}$ is called neutron self-interrogation ${ }^{4}$ (see the Appendix). The technique is currently being evaluated to determine what limitations exist to prevent its routine use for assaying plutonium in the presence of high americium concentrations. 


\section{Selective Reduction of $\mathrm{PuCl}_{3}$ with Lanthanum Metal}

As indicated in the previous sections, calcium metal is not particularly suited for selectively removing plutonium from spent MSE salts. J. G. Reavis at Los Alamos has demonstrated the reduction of plutonium trichloride to plutonium metal by numerous reagents including calcium, magnesium, sodium, lanthanum, cerium, and cerium-cobalt alioys.15 Lanthanum metal promises to be a more selective reducing agent than calcium based on Reavis' work and the thermodynamic data of Glassner ${ }^{4}$ :

$$
\begin{array}{lr}
\mathrm{La}^{0}+\mathrm{PuCl}_{3} \rightarrow \mathrm{Pu}^{\circ} \mathrm{LaCl}_{3} & \Delta \mathrm{G}(1000 \mathrm{~K})=-24 \mathrm{kcal} / \mathrm{mole} \mathrm{LaCl}_{3} \\
\mathrm{La}^{\circ}+3 \mathrm{NaCl} \rightarrow 3 \mathrm{Na}^{0}+\mathrm{LaCl}_{3} & \Delta \mathrm{G}(1000 \mathrm{~K})=+27 \mathrm{kcal} / \mathrm{mole} \mathrm{LaCl}_{3} \\
\mathrm{La}^{0}+\mathrm{AmCl}_{3} \rightarrow \mathrm{Am}^{0}+\mathrm{LaCl}_{3} & \Delta \mathrm{G}(1000 \mathrm{~K})=0 \mathrm{kcal} / \mathrm{mole} \mathrm{LaCl}_{3} \\
2 \mathrm{La}^{0}+3 \mathrm{MgCl}_{2} \rightarrow 2 \mathrm{LaCl}_{3}+3 \mathrm{Mg}^{0} & \Delta \mathrm{G}(1000 \mathrm{~K})=-27 \mathrm{kcal} / \mathrm{mole} \mathrm{LaCl}_{3} .
\end{array}
$$

Based on the above chemical equilibria, lanthanum would be expected to reduce $\mathrm{PuCl}_{3}$ and $\mathrm{MgCl}_{2}$ but not react appreciably with $\mathrm{AmCl}_{3}$ or the other salt components. This should result in a qualitatively plutonium-free salt with americium equilibrating between salt and metal phases.

From Research Chemicals in Phoenix, Arizona, we obtained lantinanum rods, 99.98 purity, encased in wax to retard oxidation. After cleaning the lanthanum, a tantaium extension rod was attached to allow some control over the rate of lanthanum addition to the molten salt. When the salt reached $700^{\circ} \mathrm{C}$, the lanthanum was lowered into the molten MSE salt while the salt was jtirred at $-400 \mathrm{rpm}$. In contrast to calcium reactions with MSE salts, no exothermic reaction was observed with the lanthanum.

Upon breakout, no pyrophoric behavior was experienced. The bulk salt was still reddish-brown, indicative of $\mathrm{AmCl}_{3}$, and there was some black salt surrounding a metal product button. In this initial run, not enough lanthanum was available for complete reaction with the $\mathrm{PuCl}_{3}$ and $\mathrm{MgCl}_{2}$, so the experinent was repeated using the same feed materials and a new lanthanum rod. During breakout of the second run, no pyrophoric behavior was observed, and the bulk salt still had the characteristic reddish-brown color of $\mathrm{AmCl}_{3}$ salts. There was still some black salt in the region around the product button, and the button 
was two-phase. The plutonium-rich region was mechanically separated from the lighter magnesium-rich region and was found to have a density of $11 \mathrm{~g} / \mathrm{cm}^{3}$ (alpha-phase plutonium has a density of $>19 \mathrm{~g} / \mathrm{cm}^{3}$ ). The magnesium region had a density of $3 \mathrm{~g} / \mathrm{cm}^{3}$ (pure magnesium has a density of $1.7 \mathrm{~g} / \mathrm{cm}^{3}$ ).

Plutonium recovery from these experiments was $\sim 86 \%$, and the product metal contained -508 impurities--principally magnesium and lanthanum. Metallographic results indicate three main regions from a cross section of the button (Fig. 11). The bottom region contains well-consolidated plutonium metal, the middle, or transition, region is composed of unconsolidated plutonium metal dispersed in a matrix of magnesium metal, and the top region largely consists of droplets and pencil-shaped inclusions of plutonium in a magnesium-rich matrix with many voids. At the upper edge of the transition region, a path of plutonium metal droplets is visible along a crack in the metal button where presumably the plutonium-rich and magnesiura-rich regions were physically separated from each other.

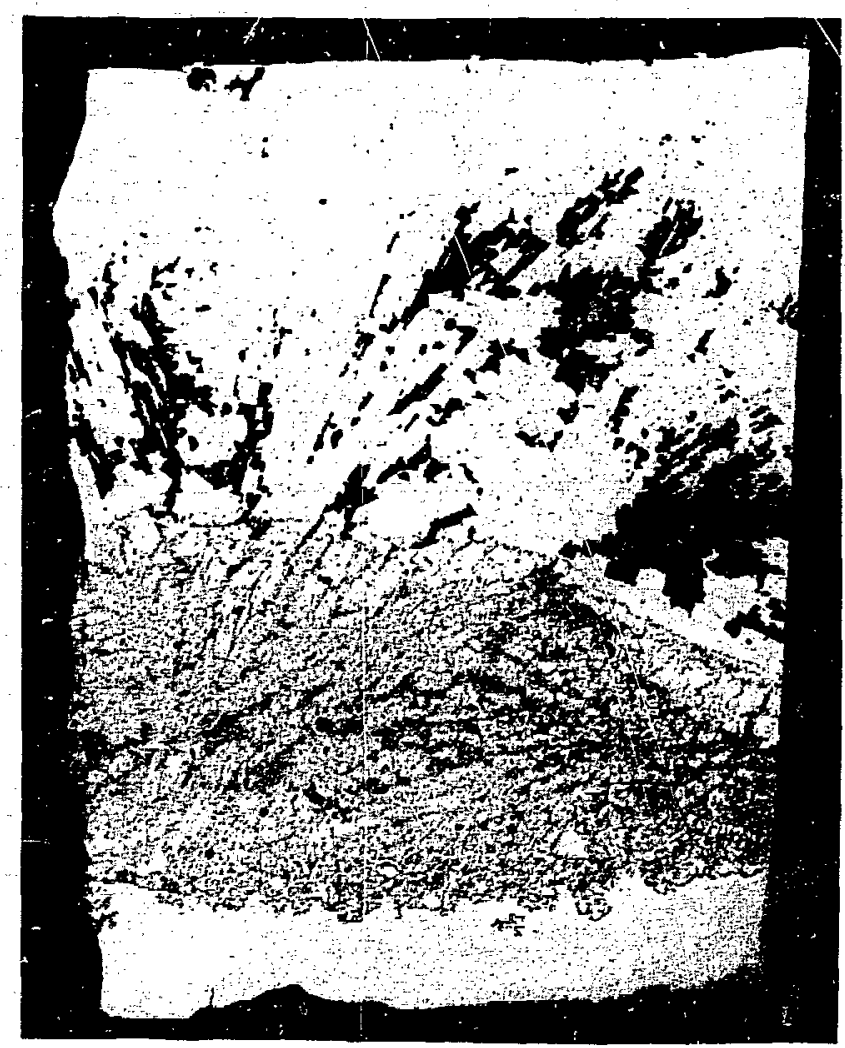

Fig. 11. As-polished cross section (5x magnification) of metal from the reduction of a spent MSE salt with lanthanum metal. 
IV. FUTURE DIRECTION

The pyrochemical approaches we have investigated for separating and recovering plutonium from spent MSE salts relied on chemical reductants for separation and on mechanical, labor-intensive techniques for recovery. From a process development standpoint, these procedures are not competitive with current aqueous chloride-anion exchange techniques. We feel that selective reduction procedures either with calcium or lanthanum show promise if we can better characterize the feed stream and improve settling or coalescence of dispersed metal phases.

We are very interestea in applying electrochemical techniques to separating and recovering plutonium from spent MSE salts. Because of the difference in oxidation-reduction potentials of plutonium and americium in different salt systems, it is very likely that controlled potential deposition can be employed to achieve good separation and recovery of plutonium from americium in some MSE salt systems.16 Application of molten salt electrochemistry to plutonium pyrochemistry is an area we are beginning to seriously investigate. It has potential not only for plutonium-americium separation, but also for plutonium-uranium separation, :or americium oxidation (ratiner than using $\mathrm{MgCl}_{2}$ in MSE), and for other plutonium purification steps throughout our pyrochemical flowsheet. 
Neutron coincidence counting assays plutonium-bearing material by detecting spontaneous fission neutrons from the plutonium in the presence of a random neutron background originating principally from $(\alpha, n)$ reactions in the material. The coincidence logic of the system separates time-correlated spontanecus fission neutrons from accidental coincidences among neutrons with random time correlations. The counter is termed a high-level coincidence counter because it is designed to handle the high counting rates associated with large masses of plutonium (several kilograms).

When a plutonium isotope undergoes spontaneous fission, two or more neutrons may be emitted almost simultaneously. The probability $\mathrm{P}(\nu)$ for $\nu$ neutrons to be emitted by the spontaneous fission of $240 \mathrm{Gu}$ is shown below. For the major plutonium isotopes, Table A-I shows the spontaneous-fission halflives, the number of spontaneous fissions per gram per second, the average number of neutrons emitted per spontaneous fission, and the number of neutrons from spontaneous fission emitted per gram per second. Because the odd-mass plutonium nuclei $\left({ }^{239} \mathrm{Pu}\right.$ and $\left.{ }^{241} \mathrm{Pu}\right)$ have very low spontanecus-fission rates, the coincidence counter measures the even-mass $\left({ }^{258} \mathrm{Pu}, 240 \mathrm{Pu}\right.$, and $\left.242 \mathrm{Pu}\right)$ plutonium content of a sample. The effective ${ }^{240} \mathrm{Pu}$ content of a sample is the nass of $240 \mathrm{Pu}$ that would give the same response to the measurement system as the actual ${ }^{238} \mathrm{Pu}, 240 \mathrm{Pu}$, and ${ }^{242} \mathrm{Pu}$ content of the sample.

Passive neutron detection gives a convenient measurement for plutonium samples because of the high neutron yields, the detector simplicity, and the neutron penetrability through the sample and storage containers. If, in addition to the coincidence rate (R), the coincidence-to-totals ratio (R/T) is

$\begin{array}{cc}\frac{\nu}{0} & \frac{\mathrm{P}(\nu)(8)}{4.9} \\ 1 & 21.4 \\ 2 & 32.1 \\ 3 & 28.2 \\ 4 & 11.2 \\ 5 & 2.1 \\ 6 & 0.1\end{array}$


TABLE A-I

Spontaneous-Fission Data for the Plutonium Isotopes

\section{Isotope}

\begin{tabular}{|c|c|c|c|c|c|}
\hline & $238 \mathrm{Pu}$ & $239 \mathrm{Pu}$ & $240 \mathrm{Pu}$ & $241 \mathrm{Pu}$ & $242 \mathrm{Pu}$ \\
\hline $\begin{array}{l}\text { Spontaneous- } \\
\text { fission half- } \\
\text { life in years }\end{array}$ & $4.9 \times 10^{10}$ & $5.5 \times 10^{15}$ & $1.17 \times 10^{11}$ & $5.0 \times 10^{15}$ & $6.8 \times 10^{10}$ \\
\hline $\begin{array}{l}\text { Spontaneous } \\
\text { fission per gram } \\
\text { per second }\end{array}$ & 1100 & 0.010 & 471 & 0.011 & 800 \\
\hline $\begin{array}{l}\text { Average number } \\
\text { of promnt neutrons } \\
\text { per fission }\left(\bar{\nu}_{p}\right)\end{array}$ & 2.26 & 2.2 & 2.17 & 2.2 & 2.16 \\
\hline $\begin{array}{l}\text { Number of } \\
\text { spontaneous- } \\
\text { fission neutrons } \\
\text { per gram } \\
\text { per second }\end{array}$ & 2490 & 0.022 & 1020 & 0.024 & 1730 \\
\hline
\end{tabular}

measured, then confirmatory information is obtained on both the fissile and fertile content. In the past, the normal procedure for making neutron measurements was to perform a simple coincidence count. This procedure works reasonably well for pure $\mathrm{PuO}_{2}$ material. However, for highly multiplying metal samples, impure oxides, high-241Am-content samples, and salts with high $(\alpha, n)$ yields, the procedure fails because of the unknown multiplication and inducedfission rates. Recently we have improved the electronics, detectors, and calculational procedures so that more accurate multiplication corrections can be made for those cases where the $(\alpha, n)$ yields are known or negligible (for example, plutonium metal). For the special cases when the $(\alpha, n)$ rates are very large and induce a significant fraction of the induced fissions, a neutron selfinterrogation method has been developed to use the $R / T$ ratio, after corrections for spontaneous fission, to directly confirm the fissile content for specific sample containers.

The passive neutrons from a plutonium sample originate from three primary sources: 
(1) spontaneous fission (SF),

(2) alpha-particle decay $(\alpha, n)$, and

(3) induced-fission multiplication (IF).

For pure metal samples, the $(\alpha, n)$ yield is zero. In general, the totals rate can be written as

$$
T=T(S F)+T(\alpha, n)+T(I F)
$$

ani when the totals rate is dominated by $(\alpha, n)$ neutrons, the rate can be written as

$$
T \simeq T(\alpha, \pi) \text {. }
$$

And the measured coincidence rate can be written as

$$
R=R(S F)+R(I F)
$$

For most cases, the spontaneous-fission rate $\mathrm{R}(\mathrm{SF})$ is obtained after the multiplication correction is made. This corrected value is proportional to the $240 \mathrm{Pu}$-effective content in the sample, where

$$
240 \mathrm{Pu} \text {-effective }=2.49238 \mathrm{Pu}+240 \mathrm{Pu}+1.57242 \mathrm{Pu}
$$

For samples with a high $(\alpha, n)$ yield, the induced-fission rate, $R(I F)$, becomes the dominant signature. In this case, we correct the measured coincidence rate for the spontaneous-fission component,

$$
R(I F)=R-R(S F)
$$

The rate, $R(I F)$, is proportional to the neutron source term, $T$, and to the mass of fissionable material. Therefore, when $R(I F)$ is normalized by the total 
neutrons, $R(I F) / T$, then the result is proportional to the fissionable material content, independent of the neutron source:

$\frac{R(I F)}{T} \propto$ fissionable content.

For the normal case of metal or $\mathrm{PuO}_{2}$ with no $(\alpha, n)$ impurities, the measured $R$ and $R / T$ give the spontaneous-fission rate and multiplication correction. For samples with unknown $(\alpha, n)$ rates, this procedure breaks down. However, if the $(\alpha, n)$ rate is very high (for example, for $\mathrm{PuF}_{4}$ and MSE salts), then the $\mathrm{R}$ (IF) term dominates and the $R(I F) / T$ ratio can be used to directly obtain the plutonium content. In this case, a correction is made to the measured coincidence rate to remove the spontaneous-fission component, $F(S F)$.

We have used an iterative technique ${ }^{17}$ to make this correction based on calibracion curves. As a first step in the iteration, the measured $R / T$ is used with the calibration curve to obtain a plutonium mass (too high). The plutonium isotopic ratics are then used to calculate $240 \mathrm{Pu}$-effective (too high), and the $24{ }^{\circ} \mathrm{Pu}$-effective curve is used to give the corresponding $\mathrm{R}(\mathrm{SF})$. The new inducedfission rate is calculated from the equation

$$
R(I F)=R-R(S F) .
$$

The new ratio $R(I F) / T$ is fit to the calibration curve to get the second iteration on $R$ (SF) (too low). This process is repeated until the value of $R(I F) / T$ converges.

Single-Can Data. To help evaluate this technique, we have measured a set of eight standards with known amounts of $\mathrm{PuF}_{4}$ and $\mathrm{PuO}_{2}$ spiked into a salt strip matrix. The goal of the work was to see if the measurements could determine the correct amount of plutonium in an arbitrary mixture of $T(\alpha, n)$ and $T(S F)$. The composition of the standards varied from all $\mathrm{PuF}_{4}$ to a 50/50 mixture of $\mathrm{PuF}_{4}$ and $\mathrm{PuO}_{2}$. The fit of the standards data to the calibration curve gave an average absolute mass residual of $1.7 \%$ for the eight standards. There is no significant difference in the assays between the samples with $1008 \mathrm{PuF}_{4}$ and the $\mathrm{PuF}_{4}+\mathrm{PuO}_{2}$ mixtures (Tables A-II and A-III). 
TABLE A-II

Description of Standard Samples

\begin{tabular}{lccc} 
Sample & $\frac{240 \mathrm{Pu}(8)}{2.523}$ & $\frac{\underline{\mathrm{puF}}_{4}(\mathrm{~g} \mathrm{Pu})(\mathrm{a})}{24.75}$ & $\frac{\mathrm{PuO}_{2}}{\left(\mathrm{~g} \_\mathrm{Pu}\right)}(\mathrm{a})$ \\
\cline { 2 - 2 } & 6.523 & 72.80 & 0 \\
MSE-3 & 6.523 & 117.90 & 0 \\
MSE-4 & 6.523 & 197.30 & 0 \\
MSE-5 & & & 0 \\
MSE-6 & 6.43 & 38.4 & \\
MSE-7 & 6.23 & 53.4 & 8.4 \\
MSE-8 & 6.04 & 37.5 & 17.2 \\
MSE-9 & 6.12 & 73.1 & 60.3
\end{tabular}

(a) The tag mass values were obtained from gamma scan data.

TABLE A-III

Self-Interrogation of $\mathrm{PuF}_{4}$ Standards and $\mathrm{PuF}_{4}+\mathrm{PuO}_{2}$ Standards $\mathrm{PuF}_{4}$ Standards

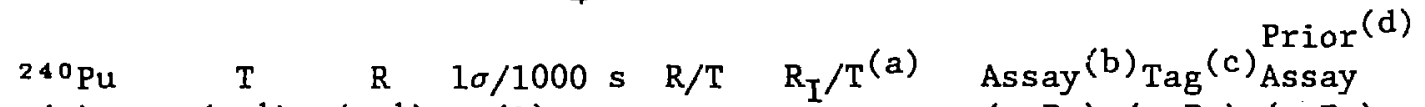
$\frac{\text { Sample }}{\text { MSE-2 }} \frac{(8)}{6.523} \quad \frac{\left(\mathrm{s}^{-1}\right)}{37341} \quad \frac{\left(\mathrm{s}^{-1}\right)}{63.9} \frac{(\mathrm{8})}{20.3} \quad 0 . \overline{00171} \overline{0.00093} \frac{(\mathrm{g} \mathrm{Pu})}{24.4} \frac{(\mathrm{g} \mathrm{Pu})}{24.75} \frac{(\mathrm{g} \mathrm{Pu})}{25.3}$

$\begin{array}{llllllllll}\text { MSE-3 } & 6.523 & 119736 & 335.3 & 13.4 & 0.00280 & 0.00206 & 73.2 & 72.8 & 75.3\end{array}$

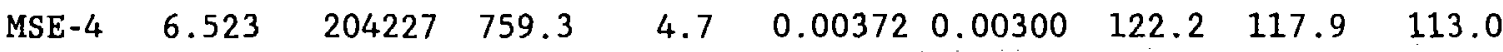

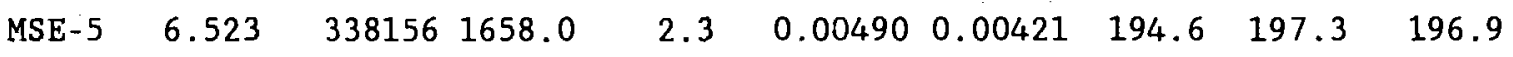
$\mathrm{PuF}_{4}+\mathrm{PuO}_{2}$ Standards

$\begin{array}{llllllllll}\text { MSE-6 } & 6.43 & 63070 & 143.6 & 16.2 & 0.00228 & 0.00144 & 44.6 & 46.8 & \text {-- }\end{array}$

$\begin{array}{llllllllll}\text { MSE-7 } & 6.23 & 91780 & 264.1 & 12.3 & 0.00228 & 0.00200 & 70.0 & 70.6 & \text { - }\end{array}$

$\begin{array}{llllllllll}\text { MSE-8 } & 6.04 & 65478 & 276.1 & 8.6 & 0.00422 & 0.00256 & 97.7 & 97.8 & \ldots\end{array}$

$\begin{array}{llllllllll}\text { MSE- } 9 & 6.12 & 133082 & 646.1 & 7.2 & 0.00485 & 0.00355 & 153.5 & 150.0 & \text { - }\end{array}$

${ }^{(a)} R_{I}$ corresponds to the induced-fission concidence rate after correction for spontaneous fission from $240 \mathrm{Pu}$-effective.

(b) The assay results were obtained from the runction $\mathrm{M}_{\text {fissionable }}=$ $328770\left(\mathrm{R}_{\mathrm{I}} / \mathrm{T}\right)^{1.3711}$, coupled with the $240 \mathrm{Pu}$-effective calibration curve.

(c) The tag results were obtained from segmented gamma scan data at TA-55.

(d) Results from a prior neutron measurement campaign on $9 / 24 / 85$. 
Actual measurements of spent MSE salts were accomplished or two separate occasions and are presented in Tables A-IV and A-V. Table A-IV gives the results for a la:-ge range of MSE salts. The average absolute difference between the tag value and the assay is $13 \%$, but based on the results for the standards, most of the uncertainty should be in the tag estimates, which were determined by segmented gamma sian techniques.

TABLE A-IV

Self-Interrogation of Spent MSE Salts

Data Summary $(9 / 24 / 85)$

\begin{tabular}{|c|c|c|c|c|c|}
\hline Sample & $\begin{array}{r}240 \mathrm{Pu} \\
(8) \\
\end{array}$ & $\begin{array}{l}T \text { net } \\
\left(s^{-1}\right) \\
\end{array}$ & $\begin{array}{c}R_{c} \\
\left(s^{-1}\right) \\
\end{array}$ & $\begin{array}{l}\text { Tag } \\
(g \quad \mathrm{Pu}) \\
\end{array}$ & $\begin{array}{l}\text { Assay (a) } \\
(\mathrm{g} \mathrm{Pu})\end{array}$ \\
\hline MSE - 2 & 6.523 & 36270 & 67 & 24.75 & 26.3 \\
\hline MSE - 2 & 6.523 & 36764 & 63 & 24.75 & 24.3 \\
\hline MSE- 3 & 6.523 & 117000 & 337 & 72.8 & 75.3 \\
\hline MSE - 4 & 6.523 & 201618 & 718 & 117.9 & 115.3 \\
\hline MSE-4 & 6.523 & 201315 & 695 & 117.9 & 110.7 \\
\hline MSE - 5 & 6.523 & 334000 & 1660 & 197.3 & 197.7 \\
\hline MSE - 5 & 6.523 & 335138 & 1655 & 197.3 & 196.2 \\
\hline XBPS - 333 & 12.73 & 65425 & 326 & 88 & 79.7 \\
\hline XBPS - 325 & 11.42 & 184500 & 908 & 159 & 144.4 \\
\hline XBPS - 325 & 11.42 & 185764 & 888 & 159 & 139.7 \\
\hline XBPS - 323 & 12.07 & 121250 & 429 & 105 & 79.4 \\
\hline XBPS - 337 & 12.69 & 21155 & 408 & 132 & 143.2 \\
\hline XBPS - 330 & 12.75 & 47229 & 400 & 112 & 114.0 \\
\hline XBPS - 332 & 12.72 & 23482 & 440 & 133 & 15.1 .8 \\
\hline XBPS - 326 & 11.42 & 49537 & 668 & 189 & 213.0 \\
\hline XBPS - 327 & 12.73 & 219456 & 806 & 132 & 104.4 \\
\hline XBPS - 336 & 12.69 & 112350 & 687 & 177 & 140.2 \\
\hline XBPS - 324 & 12.07 & 37300 & 336 & 93 & 106.2 \\
\hline
\end{tabular}

(a) The calibration curve $M_{\text {fissjonable }}=328770\left(R_{I} / T\right)^{1.3711}$ was used iteratively with the $240 \mathrm{Pu}$-effective calibration curve. 


\begin{tabular}{|c|c|c|c|c|c|c|c|c|c|}
\hline$\frac{\text { Sample }}{\text { XBPS-326 }}$ & $\begin{array}{l}240 \mathrm{Pu} \\
-\frac{(8)}{11.42}\end{array}$ & $\frac{\begin{array}{c}T \\
\left(s^{-1}\right)\end{array}}{50124}$ & $\frac{\begin{array}{c}R \\
\left(s^{-1}\right)\end{array}}{671.3}$ & $\begin{array}{c}1 \sigma / 1000 \\
\frac{(8)}{2.8}\end{array}$ & $\begin{array}{c}R / T \\
0 . \overline{01339}\end{array}$ & $\frac{\mathrm{R}_{\mathrm{I}} / \mathrm{T}^{(\mathrm{a})}}{0.00432}$ & $\begin{array}{l}\text { Assay } \\
\frac{(\mathrm{g} \text { Pu) }}{213.2}\end{array}$ & $\begin{array}{l}{ }_{\mathrm{Tag}}(\mathrm{c} \\
\frac{(\mathrm{g} \mathrm{Pu})}{189}\end{array}$ & $\begin{array}{l}\text { Prior }(\mathrm{d}) \\
\text { Assay } \\
\frac{(\mathrm{g} \mathrm{Pu})}{213.0}\end{array}$ \\
\hline XBPS - 330 & 12.75 & 47435 & 393.4 & 4.5 & 0.00829 & 0.00267 & 111.8 & 112 & 114.0 \\
\hline XBFS - 333 & 12.73 & 65796 & 315.2 & 7.6 & 0.00479 & 0.00202 & 76.4 & 88 & 79.7 \\
\hline XBPS - 334 & 12.73 & 73438 & 537.7 & 5.1 & 0.00732 & 0.00302 & 132.5 & 155 & - \\
\hline
\end{tabular}

(a) $\mathrm{R}_{\mathrm{I}}$ corresponds to the induced-fission coincidence rate after correction for spontaneous fission from $240 \mathrm{Pu}$-effective.

(b) The calibration curve $M_{\text {fissionable }}=328770\left(R_{I} / T\right)^{1.3711}$ was used iteratively with the $240 \mathrm{Pu}$-effective calibration curve.

(c) The tag results were obtained from segmented gamna scan data at TA-55.

(d) Results from a prior neutron measurement campaign on $9 / 24 / 85$.

For the MSE salt data presented in Table A-III, the statistical error for single measurements of $1000 \mathrm{~s}$ is given in column 5 . The $1 \sigma$ values (1000 s) for the salt samples ranged from 2.8 to 7.68 depending on plutonium mass loading and the $(\alpha, n)$ neutron interrogation strength. The same calibration curve (Fig. A-1) was used for Tables A-III through A-V. In general, the statistical error for the spent MSE salts was Iower than for the standards because of the larger plutonium mass and the high $(\alpha, n)$ rates in the MSE salts.

The present MSE salts are in cans with a diameter of $10 \mathrm{~cm}$ and a fill height of $9-11 \mathrm{~cm}$. Most of the volume $(0.8 \mathrm{l})$ is filled with the salt matrix $(-1 \mathrm{~kg})$, and only about 48 of the space is occupied by plutonium compounds. The neutron leakage multiplication is less than 1.02 under these mass and volume conditions. Thus, the probability of a neutron born from spontaneous fission causing an induced fission $\left(R_{I}\right)$ is small. The primary source of induced fission is the $(\alpha, n)$ neutrons originating from the ${ }^{241} \mathrm{Am}$ alpha decay in the salt matrix.

The question comes up as to what level of impurity will satisfy the simple self-interrogation algorithm. When a neutror born from spontaneous fission or. induced fission causes an additional fission, the measured $R_{I}$ is larger than that for an $(\alpha, n)$ neutron-induced fission because of the higher effective neutron multiplicity. For pure $\mathrm{PuO}_{2}, \mathrm{~T}(\alpha, \mathrm{n}) \approx \mathrm{T}(\mathrm{SF})$, and for pure $\mathrm{PuF}_{4}$, $\mathrm{T}(\alpha, \mathrm{n}) \simeq 120 \mathrm{~T}(\mathrm{SF})$. The perturbation in $\mathrm{R}_{\mathrm{I}}$ from spontaneous-fission source neutrons can be neglected for $T(\alpha, n) \gg T(S F)$. Practically speaking, the 


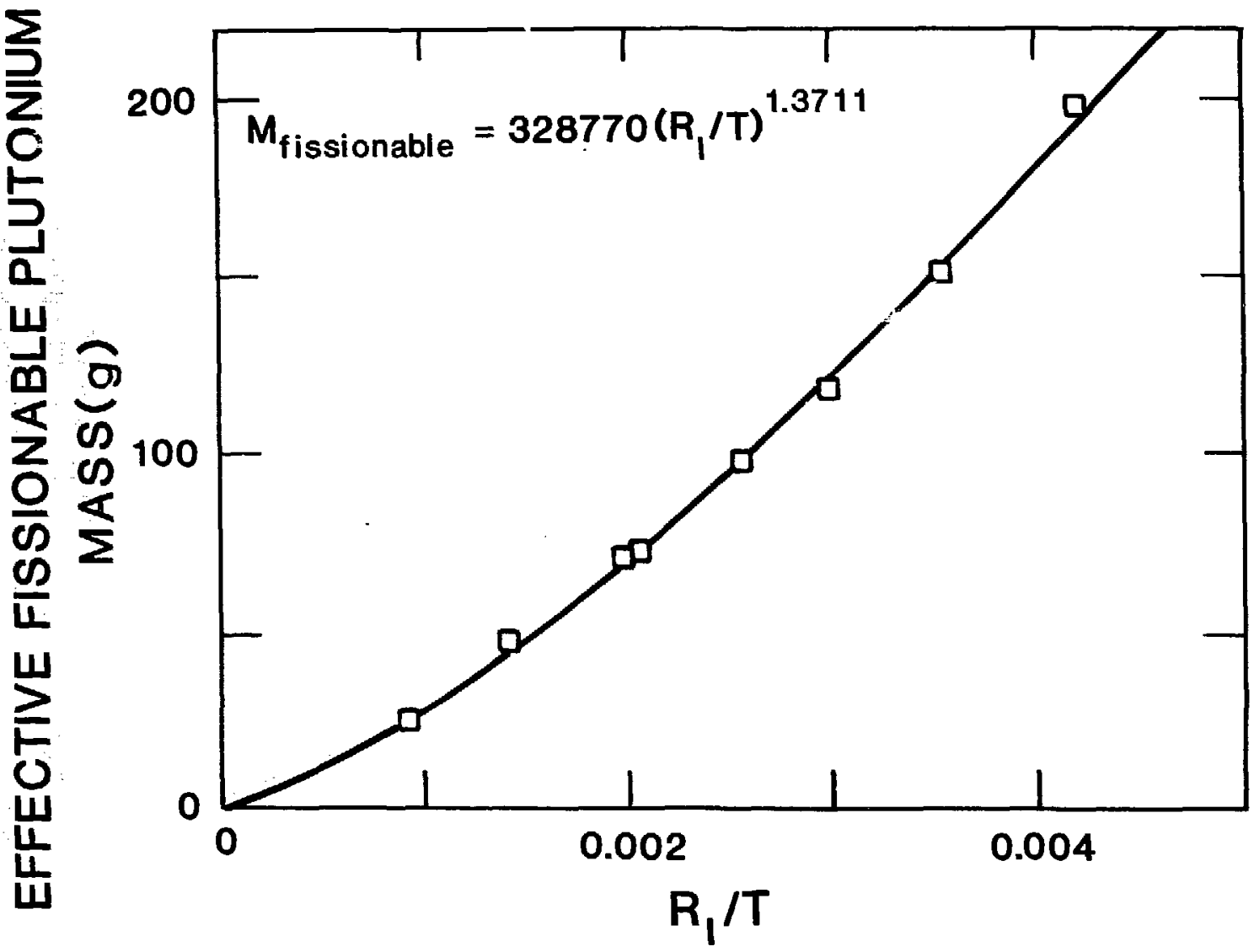

Fig. A-1. Neutron self-interrogation calibration curve.

neutron rate from a sample should be at least 3 times higher than that for a pure $\mathrm{PuO}_{2}$ sample before the above technique can be used.

When we apply the same calibration curve (Fig. A-1) and calculational algorithm to $\mathrm{PuO}_{2}$ standard in a salt matrix, we obtain a mass of $132 \mathrm{~g}$ plutonium compared with the true value of $120 \mathrm{~g}$. The increase in the measured $\mathrm{R} / \mathrm{T}$ ratio is zaused by the increase in the fraction of spontaneous-fission neutrons compared with that in the $\mathrm{PuF}_{4}$ standards. For the $\mathrm{PuO}_{2}$ standard, the observed $\alpha$ value $[(\alpha, n) / S F$ ratio] was only a factor of 2.4 larger than the value for pure $\mathrm{PuO}_{2}$. As another example, a can of pure $\mathrm{PuO}_{2}$ with a tag plutonium mass of $172 \mathrm{~g}$ assayed at $205 \mathrm{~g}$ using the $\mathrm{P}_{\mathrm{I}} / \mathrm{T}$ calibration curve (Fig. A-1). In this case the plutonium volume was decreased (because of the absence of salt matrix), which also will increase the assay result. 
Double-Gan Data. In the self-interrogation method, we make the assumption that the measured totals rate is proportional to the neutron flux that induces the fissions. If the sample shape changes significantly, this is no longer true.

To experimentally study this effect, we measured pairs of cans stacked on top of each other. This increases the apparent sample fill height from $10 \mathrm{~cm}$ to $22 \mathrm{~cm}$. The description of the can combinations is given in Table A-VI. There is a 3 - to $4-\mathrm{cm}$ void between the top of the salt in the bottom can and the bottom of the top can.

If there were no neutron coupling between the cans, then the $\mathrm{R}_{\mathrm{I}} / \mathrm{T}$ calibration curve for a single can would give the average mass for the double can rather than the sum of the two cans. For example, with two identical cans and no crosstalk, then $R$ would double and $T$ would double but $R / T$ would remain the same as for a single can. In our double-can geometry, there is coupling that is about 308 as large as if all of the mass were inside a single can.

The results of the measurements are shown in Fig. A-2 where the $R_{I} / T$ ratio versus grams of fissionable plutonium is plotted. The previous single-can data are given for comparison. The curve fitted through the double-can data has an average absolute mass residual of 2.08 . If the double-can results are normalized to the single-can calibration curve, the normalization factur for the mass is 1.30. After this normalization, the double cans have an average absolute mass residual of 3.08 when fit to the single-can calibration curve. In general, the neutron flux coupling correction factor can be calculated for any sample geometry. A correction for this effect would reduce the proliferation of calibration curves.

TABLE A-VI

Double-Can Data (12/3/85)

\begin{tabular}{|c|c|c|c|c|c|c|c|c|}
\hline$\frac{\text { Sample }}{\text { MSE }-6+7}$ & $\begin{array}{c}\mathbf{P u} \\
\frac{(\mathrm{g})}{117.4}\end{array}$ & $\begin{array}{l}24{ }^{\circ} \mathrm{Pu} \\
\frac{(8)}{6.31}\end{array}$ & $\begin{array}{l}240 \text { Pu-eff } \\
\frac{(8)}{7.53}\end{array}$ & $\frac{{ }_{\left.S^{-1}\right)}^{R_{S^{-1}}}}{136.6}$ & $\frac{\begin{array}{l}R_{\text {meas }} \\
(\mathrm{s}-1)\end{array}}{462.0}$ & $\begin{array}{l}R_{I} \\
\frac{\left(s^{-1}\right)}{325.4}\end{array}$ & $\frac{\left(\begin{array}{c}\mathrm{T} \\
\left(s^{-1}\right)\end{array}\right.}{154500}$ & $\begin{array}{l}\mathrm{R} / \mathrm{T} \\
\times 10 \\
0.211\end{array}$ \\
\hline MSE $-6+8$ & 144.6 & 6.17 & 9.07 & 164.5 & 482.9 & 318.4 & 128713 & 0.247 \\
\hline MSE $-7+8$ & 168.4 & 6.12 & 10.48 & 190.0 & 626.8 & 436.7 & 156933 & 0.278 \\
\hline MSE $-6+9$ & 196.8 & 6.19 & 12.38 & 224.6 & 879.8 & 654.8 & 195953 & 0.334 \\
\hline MSE $-7+9$ & 220.6 & 6.16 & 13.81 & 250.6 & 1042.8 & 792.2 & 224489 & 0.353 \\
\hline$M S E-8+9$ & 247.8 & 6.09 & 15.32 & 278.3 & 1078.2 & 799.9 & 197715 & 0.405 \\
\hline
\end{tabular}




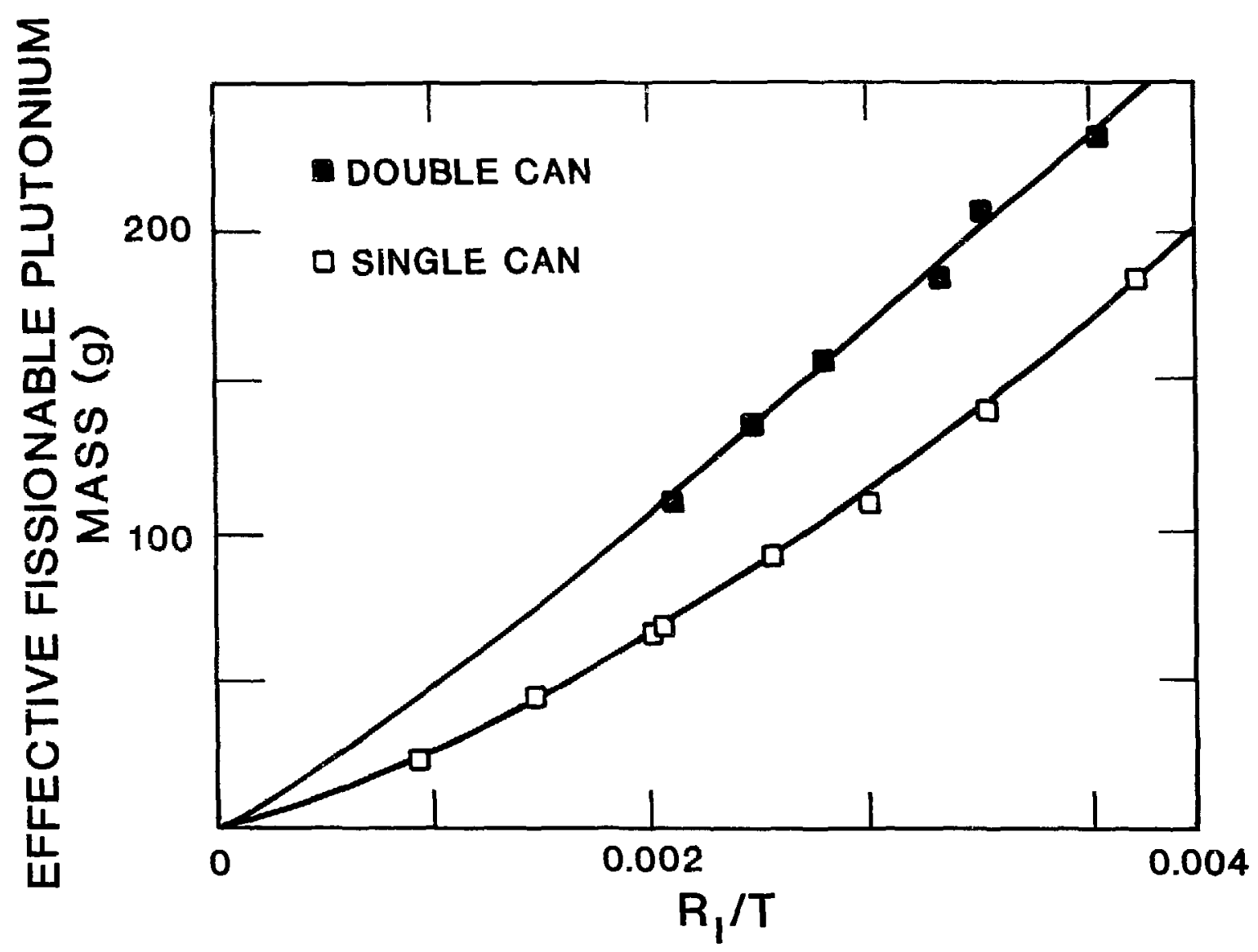

Fig. A-2. Double-can measurements on the single-can calibration curve.

Summary. All of the salt standards were measured with an accuracy consistent with counting statistics (1-38). The average absolute mass residual was 1.78 for the calibration curve shown in Fig. A-1. The glove box neutron coincidence counters at TA-55 are being updated with bias-free, low-dead-time electronics including the AMPTEK amplifiers. This should make it possible to measure spent MSE salts with the in-line neutron counters at TA-55. 
1. D. C. Christensen and L. J. Mullins, "Present Status of Plutonium Metal Production and Purification at Los Alamos - 1982," Los Alamos National Laboratory report LA-9674-MS (June 1983).

2. L. J. Mullins, J. A. Leary, and W. J. Maraman, "Removal of Fission Product Elenents by Slagging," Ind. Eng. Chem. 52, 227 (March 1960).

3. J. B. Knighton, R. G. Auge, J. W. Berry, and R. C. Franchini, "Molten Salt Extraction of Americium from Molten Plutonium Metsi, " Rockwell International report RFP 2365 (March 1976).

4. A. Glassner, "The Thermodynamic Properties of the Oxides, Fluorides, and Chlorides to $2500 \mathrm{~K}$," Argonne National Laboratory report ANL-5750 (1957).

5. L. R. Avens, D. G. Clifton, and A. R. Vigil, "Actinide Recovery from Pyrochemical Residues," Los Alamos National Laboratory report LA-10281-MS (May 1985).

6. L. W. Gray and J. H. Gray, "Aqueous Recovery of Plutonium from Pyrochemical Processing Residues," in Proceedings of the International Symposium on Actinide/Lanthanide Separations, G. R. Choppin et a1. (eds.), Wor1d Scientific Publishers, Singapore, pp. 294-313 (1985).

7. R. L. Nance and S. L. Yarbro, "Precipitation Process for Pu-Am Recovery from MSE Salts," Poster presented at the 10th Actinide Separations Workshop, May 12-14, 1986, Los Alamos, New Mexico.

8. K. W. Fife, M. H. West, R. L. Nance, and S. L. Yarbro, "An Integrated Pyrochemical Aqueous Procedure for Recovering Plutonium From Spent MSE Salts," Poster presented at the 10th Actinide Separations Workshop, May 12-14, 1986, Los Alamos, New Mexico.

9. J. B. Kníghton and R. J. Steunenberg, "Distribution of Transuranium Elements Between Magnesium Chloride and Zinc-Magnesium Alloy," J. Inorg. Nuc1. Chem. 27, 1457 (1965).

10. M. J. Cusick, W. G. Sherwood, and R. F. Fitzpatrick, "Plutonium and Americium Recovery from Spent Molten Salt Extraction Salts with Al-Mg Alloys," Rockwell International report RFP-3614 (April 1984).

11. D. C. Christensen and L. J. Mullins, "Salt Stripping, a Pyrochemical Approach to the Recovery of Plutonium Electrorefining Salt Residues," Los Alamos National Laboratory report LA-9464-MS (October 1982).

12. K. W. Fife, D. C. Christensen, and J. D. Williams, "Plutonium and Americium Separation from Molten Salt Extraction Waste Salts," in Proceedings of the International Symposium on Actinide/Lanthanide Separations G. R. Choppin et al. (eds.), World Scientific Pub1ishers, Singapore, PP. $313-326$ (1985). 
13. M. S. Krick and H. O. Menlove, "The High-Level Neutron Concidence Counter (HLNCC): Users' Manual, "Los Alamos Scientific Laboratory report LA-7779-M (June 1979).

14. H. O. Menlove, Los Alallus National Laboratory, Group N-1, private communication (September 1985).

15. J. G. Reavis, "Plutonium Metal and Alloy Preparation by Molten Chloride Reduction," in Proceedings of the International Symposium on Actinide/ Lanthanide Separations, G. R. Choppin et al. (eds.), World Scientific Publishers, Singapore, pp. 348-360 (1985).

16. K. W. Fife, "Recovery of Piutnnium from MSE Waste Salts by Molten Salt Electrochemical Techniques," Los Alamos National Laboratory document LA-UR-85-156 (May 1985).

17. H. 0. Menlove, "Neutron Counting for Confirmatory Measurements," Proceedings of the $26^{\text {th }}$ Annual Meeting of the Institute of Nuclear Materials Management, J. Inst. Nucl. Mater. Manage. XIV(3), $589-594$ (1985). 